Dhaka Univ. J. Biol. Sci. 30(1): 35-47, 2021 (January)

\title{
METAL CONCENTRATION IN COMMONLY SOLD FRUIT VEGETABLES IN DHAKA CITY MARKET AND PROBABLE HEALTH RISK
}

\author{
Romana Sultana, AS Chamon*, MN Mondol and I TASnim \\ Department of Soil, Water and Environment, University of Dhaka, \\ Dhaka-1000, Bangladesh
}

Key words: Fruit vegetables, Kawran Bazar market, Metal concentration, Average daily intake, Health risk

\begin{abstract}
The present study evaluated the concentration of heavy metals in six different fruit vegetables collected from Kawran Bazar market of Dhaka city of Bangladesh. The analyzed fruit vegetable samples were randomly collected, processed and analyzed for heavy metal determination using atomic absorption spectrophotometry (AAS). Mean concentrations $\left(\mathrm{mg} \mathrm{kg}^{-1}\right)$ of $\mathrm{Cr}, \mathrm{Cd}, \mathrm{Pb}, \mathrm{Ni}, \mathrm{Cu}$, $\mathrm{Zn}, \mathrm{Fe}$ and Mn of Lady's finger, Pumpkin, Tomato, Brinjal, Snake gourd and Cucumber were within the range of 0.83 to $4.88,0.08$ to $0.18,0$ to $3.00,0.33$ to $3.70,8.10$ to $10.88,17.81$ to $45.91,53.00$ to 131.50 and 10.40 to $45.90 \mathrm{mg} \mathrm{kg}^{-1}$ of dry weight, respectively. Mean concentration ( $\mathrm{mg} \mathrm{kg}^{-1}$ ) of $\mathrm{Cr}$ in Brinjal (4.88); $\mathrm{Pb}$ in Pumpkin (3.00) and Brinjal (0.50); Ni in Snake gourd (3.70); Cu in Lady's finger (10.10), Brinjal (10.88), Snake gourd (10.53) and Cucumber (10.48) were higher than the maximum permissible limit (MPL). The study suggests regular monitoring of heavy metals in vegetables to prevent excessive accumulation in human body.
\end{abstract}

\section{Introduction}

In recent years, there has been an increasing ecological and global public health concern associated with environmental contamination by heavy metals. Heavy metals are extremely persistent in the environment; they are non-biodegradable and non-thermo degradable and thus readily accumulate to toxic levels. Although heavy metals are naturally occurring elements that are found throughout the earth's crust, most environmental contamination and human exposure result from anthropogenic.

Food is the major source of heavy metals intake by human beings. Vegetables are most exposed food to the environmental pollution due to aerial burden among different food systems. They are consumed enormously almost in every country and thus constitute the major food source. Vegetables constitute an important part of the human diet since they contain carbohydrates, proteins, vitamins, minerals as well as trace elements. They are very important protective food and useful for the maintenance of

*Author for correspondence: <chamonafrose@du.ac.bd>.

DOI: https://doi.org/10.3329/dujbs.v30i1.51807 
health and the prevention and treatment of various diseases. The contamination of vegetables with heavy metals due to soil and atmospheric contamination poses a threat to its quality and safety.

Dietary intake of heavy metals poses risk to animals and human health. Most of the heavy metals are extremely toxic because of their solubility in water. Even low concentrations of heavy metals have damaging effects to man and animals because there is no good mechanism for their elimination from the body. High concentrations of heavy metals $(\mathrm{Cu}, \mathrm{Cd}, \mathrm{Cr}, \mathrm{Pb}, \mathrm{Ni}, \mathrm{Fe}, \mathrm{Mn}$ and $\mathrm{Zn})$ in vegetables were related to high prevalence of cancer ${ }^{(1)}$. It is therefore necessary to assess the level of heavy metal contents in different varieties of vegetables to ensure the food safety. Lack of scientific knowledge of cultivation, use of wastewater, pesticides, insecticides, fertilizers etc. which are significant source of heavy metals and thus contaminating vegetables grown in that condition (2).

Heavy metal in vegetables is of growing concerns since some soils and irrigation water are demonstrated to be polluted. Vegetables easily take up heavy metals and accumulate them in their edible parts. The uptake and bioaccumulation of heavy metals in vegetables are influenced by many factors such as climate, atmosphere depositions, the concentrations of heavy metals in soil, the nature of soil and the degree of maturity of the plants at the time of harvesting(3). Air pollution may pose a threat to post-harvest vegetables during transportation and marketing causing elevated levels of heavy metals in vegetables ${ }^{(4)}$. In a developing country like Bangladesh, urbanization and industrialization may significantly contribute to elevated heavy metal loads in atmosphere as well as in soil which consequently increases the heavy metals concentration in vegetables and fruits to a toxic level. As Dhaka is experiencing the rapid industrialization and urbanization, focusing on food safety aspect, attempt should be taken to determine the heavy metal concentrations in vegetables available in Dhaka city markets.

\section{Materials and Methods}

Study area: The present study was carried out by collecting samples from Kawran Bazar vegetable market, Dhaka. Kawran Bazar is the biggest and most famous wholesale market of Dhaka city. The vegetables in this market mainly come from Savar, Munshiganj, Narsingdi, Mymensingh, Kishoregonj, Rajshahi, Jessore, Kushtia, Bogra, Chittagong etc. All kinds of vegetables, fish, rice and different commodities are supplied to the other fresh markets of Dhaka city from Kawran Bazar. Therefore, this study gave a representative result of vegetables found in other vegetable markets of Dhaka city.

Sample collection: Six different native fruit vegetable samples were collected in 4 phases with at least 14 days interval for 2 months. In each sampling phase fresh raw samples of the fruit vegetables were randomly purchased and brought to the laboratory. 
The name of the vegetables were: Lady's finger (Abelmoschus esculentus), Pumpkin (Cucurbita maxima), Tomato (Solanum lycopersicum), Brinjal (Solanum melongena), Snake gourd (Trichosanthes cucumerina) and Cucumber (Cucumis sativus).

Sample preparation and preservation: The collected vegetable samples were washed thoroughly with fresh tap water and rinsed three times with distilled water to remove surface pollutants and any items adhering to the surfaces. Samples were sliced into small pieces and air dried on paper for about $2 \mathrm{~h}$ to eliminate excess moisture. Fresh weight of each sample was taken, then dried in an oven at $60-70^{\circ} \mathrm{C}$ for $72-96 \mathrm{~h}$ depending on the sample size and reweighed to determine the dry weight. The dried vegetable samples were ground by pestle and mortar and passed through a $0.2 \mathrm{~mm}$ sieve to obtain homogenized sample. The powdered samples were then preserved in polythene bags at ambient temperature before analysis.

Digestion of the sample: One gram of the oven dried sample was weighed into $100 \mathrm{ml}$ beaker, followed by the addition of $10 \mathrm{ml}$ conc. $\mathrm{HNO}_{3}$ and $2 \mathrm{ml}$ conc. $\mathrm{HClO}_{4}$. The digestion was carried out on a hot plate at $150-200^{\circ} \mathrm{C}$. After digestion, the samples were cooled, filtered, made up to $100 \mathrm{ml}$ in a volumetric flask and then preserved in plastic bottle for analysis.

Analysis of the samples: Concentration of heavy metals i.e. Chromium, Cadmium, Lead, Nickel, Copper, Zinc, Iron and Manganese in the extracts were analyzed by using Varian AA 240 Atomic Absorption Spectrophotometer (AAS).

Average Daily Intake (ADI): The ADI of a heavy metal was calculated as shown in the following equation ${ }^{(5)}$ :

$$
\mathrm{ADI}=\mathrm{Av} \text { consumption } \times \% \mathrm{DW} \text { vegetable } \times \mathrm{C}_{\text {heavy metal }}
$$

Where ADI is average daily intake of heavy metal per person per day (mg/ person/day), Av consumption is average daily consumption of vegetable per person per day (g/day), \% DW vegetable is percentage of dry weight of vegetable $(\% \mathrm{DW}=[(100-$ $\%$ moisture)/100]), and $C$ heavy metal is average heavy metal concentration of dry weight vegetable $(\mathrm{mg} / \mathrm{g})$. The average daily consumption of vegetables reported by Household Income and Expenditure Survey of Bangladesh is $166.1 \mathrm{~g}$ per person(6). The value 166.1 $\mathrm{g}$ /person/day is used in calculating the ADI values and an average weight of person is considered to be $60 \mathrm{~kg}^{(7)}$. If the ADI is above the maximum permissible daily intake (MTDI) value, it may cause various health hazards.

Hazard Quotient (HQ): Hazard quotient is a proportion of the probable exposure to an element/chemical and level at which no negative impacts are expected. When the quotient is $<1$, this means no potential health effects are expected from exposure, but when it is $>1$, it signifies that there are potential health risks due to exposure ${ }^{(8)}$. The HQ is 
calculated as a fraction of determined dose to the reference dose as shown in the following equation:

$$
\mathrm{HQ}=\mathrm{ADI} / R_{\mathrm{f}} D
$$

Where ADI is the average vegetables intake per day $\left(\mathrm{mg} \mathrm{kg}^{-1}\right)$ and $R_{\mathrm{f}} D$ is the oral reference dose of the metal $\left(\mathrm{mg} \mathrm{kg}^{-1}\right) \cdot R_{\mathrm{f}} D$ is an approximation of daily tolerable exposure to which a person is expected to have without any significant risk of harmful effects during a lifespan. $\mathrm{R}_{\mathrm{f}} \mathrm{D}$ for $\mathrm{Pb}, \mathrm{Zn}, \mathrm{Cu}, \mathrm{Cd}, \mathrm{Cr}, \mathrm{Ni}, \mathrm{Fe}$ and $\mathrm{Mn}$ is 0.004, 0.3, 0.04, 0.0005, $0.003,0.02,0.7$ and $0.14 \mathrm{mg} \mathrm{kg}^{-1} \mathrm{day}^{-1}$, respectively ${ }^{(9)}$.

Hazard Index (HI): An exposure to more than one pollutant results in additive effects. Thus, hazard index (HI) is a vital index that assesses overall likely impacts that can be posed by exposure to more than one contaminant. When the $\mathrm{HI}$ is $>1$, this suggests that there are significant health effects from consuming pollutants contained in a foodstuff. The $\mathrm{HI}$ is calculated as an arithmetic sum of the hazard quotients for each pollutant as shown in the following equation ${ }^{(5)}$ :

$$
\mathrm{HI}=\sum_{i=1}^{n} H Q
$$

Statistical analysis: The results of the experiment were statistically evaluated by using ANOVA (Analysis of Variance) and Duncan's Multiple Range Test in IBM SPSS statistics version 20 as outlined by Gomez and Gomez ${ }^{(10)}$. The letter was used for testing the significance of differences between mean values. The 0.05 level of probability was chosen for the statistical judgment.

\section{Results and Discussion}

Metal concentration in vegetables: Mean concentrations of the heavy metals in the studied fruit vegetables revealed significant variation ( $\mathrm{p} \varangle 0.05$ ) except for $\mathrm{Cr}, \mathrm{Cd}$ and $\mathrm{Cu}$ (Table 1). This variation could be attributed to differences in absorption capacities of the vegetables and their translocation within the plants. Mean concentrations of $\mathrm{Cr}, \mathrm{Cd}, \mathrm{Pb}$, $\mathrm{Ni}, \mathrm{Cu}, \mathrm{Zn}, \mathrm{Fe}$ and $\mathrm{Mn}$ in the studied fruit vegetables were within the range of 0.83 to $4.88,0.08$ to $0.18,0$ to $3.00,0.33$ to $3.70,8.10$ to $10.88,17.81$ to $45.91,53.00$ to 131.50 and 10.40 to $45.90 \mathrm{mg} / \mathrm{kg}$ of dry weight, respectively. Mean $\mathrm{Cr}$ concentration in Brinjal, $\mathrm{Pb}$ concentration in Pumpkin and Brinjal, Nickel concentration in Snake gourd, $\mathrm{Cu}$ concentration in Lady's finger, Brinjal, Snake gourd and Cucumber were found to be higher than the Maximum Permissible Limit (MPL) recommended by FAO WHO$^{(11)}$.

Concentration of $\mathrm{Cr}$ was also found to be higher in Tomato collected in $4^{\text {th }}$ phase and in Brinjal collected in $1^{\text {st }}$ and $3^{\text {rd }}$ phase of sampling. Cadmium concentration was found to be higher than the MPL suggested by FAO MHO (12) in Cucumber collected in $2^{\text {nd }}$ phase 


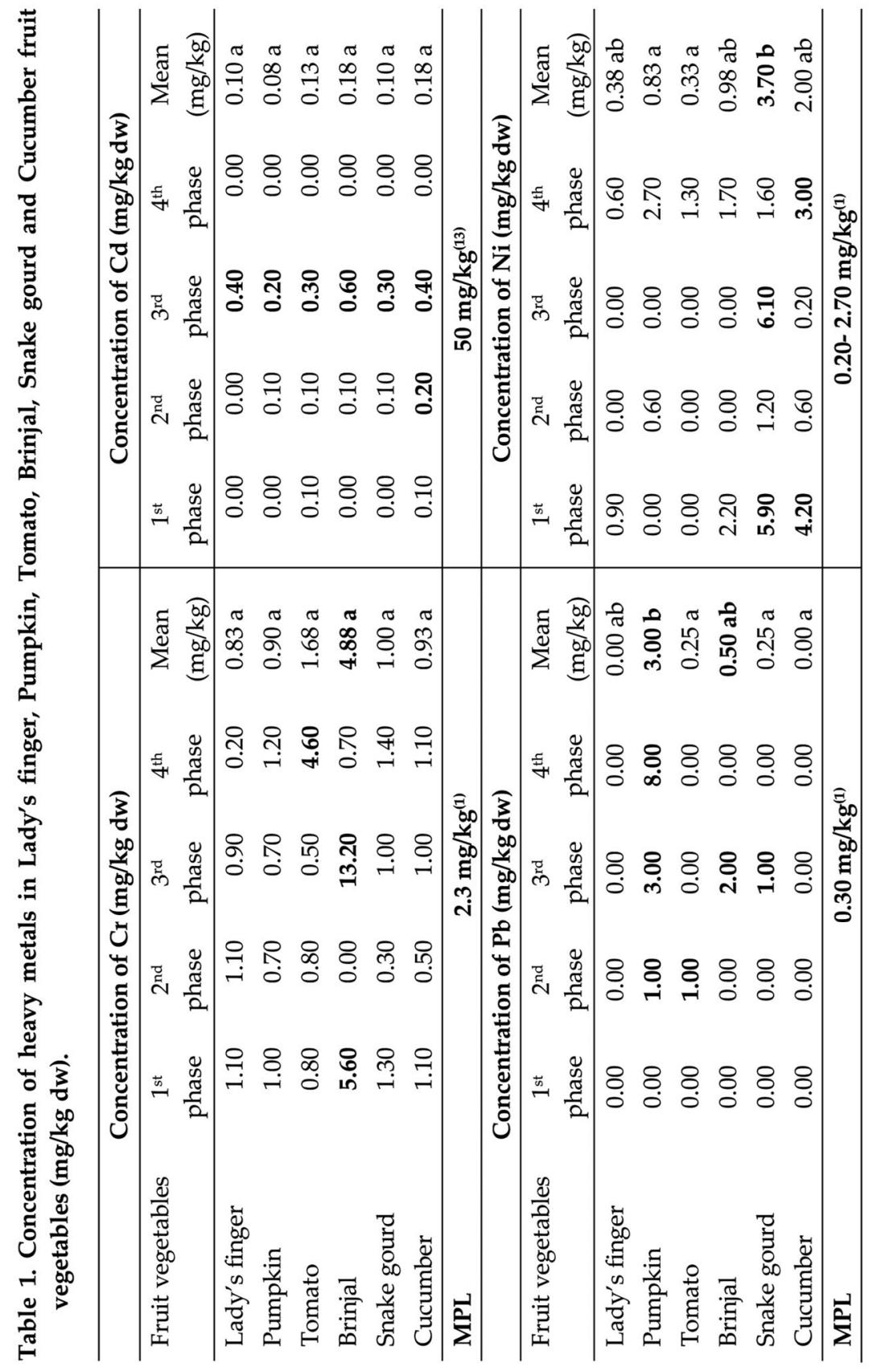




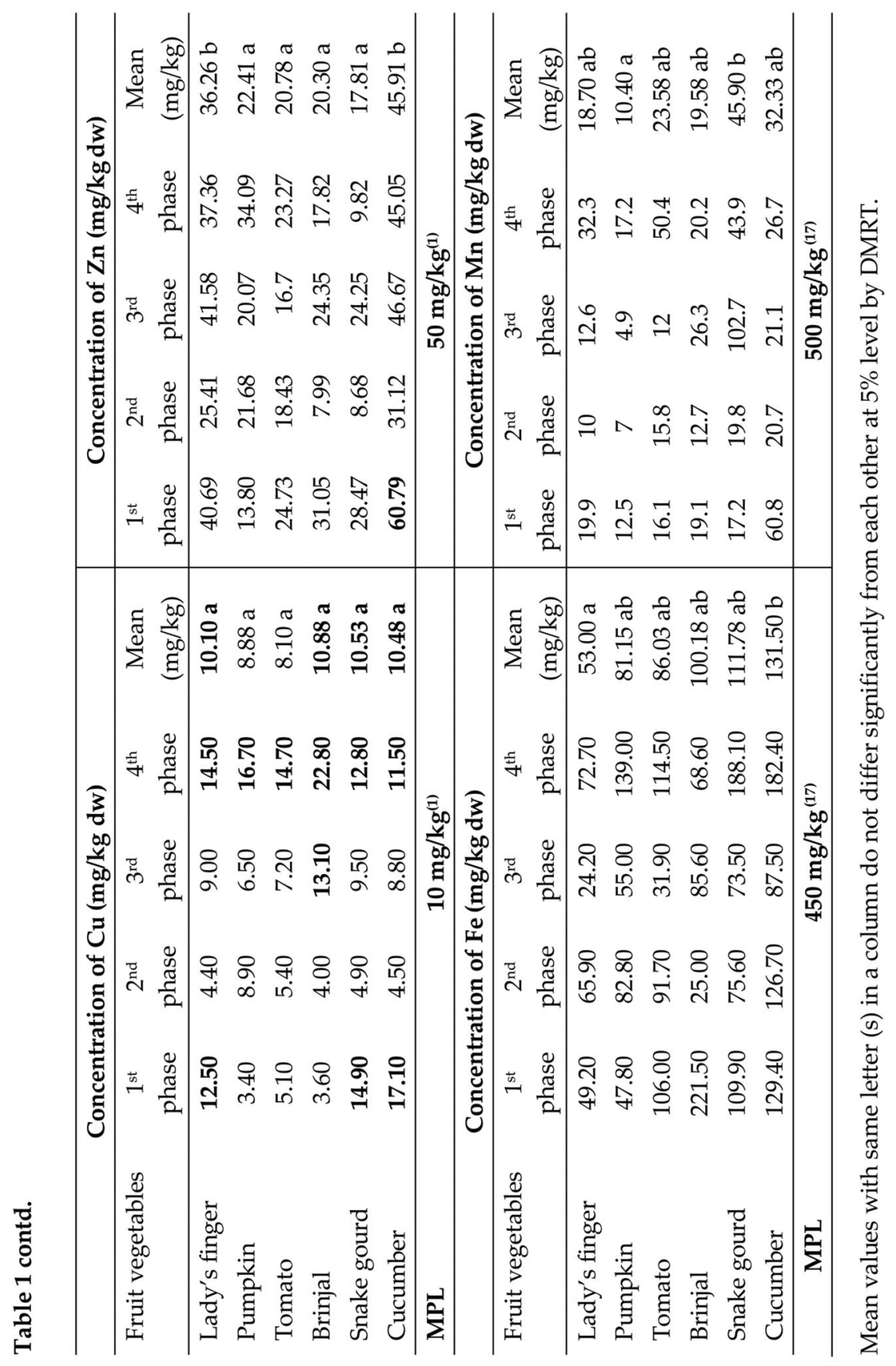


and in all the studied fruit vegetables collected in $3^{\text {rd }}$ phase of sampling. Pumpkin collected in $2^{\text {nd }}, 3^{\text {rd }}$ and $4^{\text {th }}$ phase, Tomato collected in $2^{\text {nd }}$ phase, Brinjal and Snake gourd collected in $3^{\text {rd }}$ phase showed higher concentration of $\mathrm{Pb}$ then the MPL. Concentration of $\mathrm{Ni}$ was higher than the MPL in Snake gourd collected in $1^{\text {st }}$ and $3^{\text {rd }}$ phase and in Cucumber collected in $1^{\text {st }}$ and $4^{\text {th }}$ phase of sampling. Lady's finger, Snake gourd and Cucumber collected in the $1^{\text {st }}$ phase, Brinjal collected in $3^{\text {rd }}$ phase and all fruit vegetables collected in the $4^{\text {th }}$ phase showed higher $\mathrm{Cu}$ concentration than the MPL. Concentration of $\mathrm{Zn}, \mathrm{Fe}$ and Mn were below the MPL collected in all phases except for $\mathrm{Zn}$ concentration in Cucumber collected in $1^{\text {st }}$ phase of sampling.

Highest mean concentrations of $\mathrm{Cr}$ and $\mathrm{Cu}$ were observed in Brinjal, $\mathrm{Pb}$ in Pumpkin, $\mathrm{Ni}$ and $\mathrm{Mn}$ in Snake gourd, $\mathrm{Zn}$ and Fe in Cucumber and $\mathrm{Cd}$ in Brinjal and Cucumber. Lowest mean concentrations of $\mathrm{Cr}$ and $\mathrm{Fe}$ were found in Lady's finger, $\mathrm{Cd}$ and $\mathrm{Mn}$ in Pumpkin, $\mathrm{Ni}$ and $\mathrm{Cu}$ in Tomato, $\mathrm{Zn}$ in Snake gourd and $\mathrm{Pb}$ in Lady's finger and Cucumber. The comparison among the studied fruit vegetables revealed that mean $\mathrm{Cr}$ concentrations decreased in the order of Brinjal $>$ Tomato $>$ Snake gourd $>$ Cucumber $>$ Pumpkin $>$ Lady's finger, mean $\mathrm{Cd}$ concentration decreased in order of Brinjal and Cucumber $>$ Tomato $>$ Lady's finger and Snake gourd $>$ Pumpkin, mean $\mathrm{Pb}$ concentration decreased in order of Pumpkin $>$ Brinjal $>$ Tomato and Snake gourd, mean Ni concentration decreased in order of Snake gourd $>$ Cucumber $>$ Brinjal $>$ Pumpkin $>$ Lady's finger $>$ Tomato, mean $\mathrm{Cu}$ concentrations decreased in order of Brinjal $>$ Snake gourd $>$ Cucumber $>$ Lady's finger $>$ Pumpkin $>$ Tomato, mean $\mathrm{Zn}$ concentration decreased in order of Cucumber $>$ Lady's finger $>$ Pumpkin $>$ Tomato $>$ Brinjal $>$ Snake gourd, mean Fe concentration decreased in the order of Cucumber $>$ Snake gourd $>$ Brinjal $>$ Tomato $>$ Pumpkin $>$ Lady's finger and mean Mn concentration decreased in the order of Snake gourd $>$ Cucumber> Tomato> Brinjal>Lady's finger $>$ Pumpkin. But, lead concentration was below the detectable limit in Lady's finger and Cucumber in all phases.

In previous studies, zinc, lead and cadmium concentration was found to be higher in fruit vegetables of Turag river side fields of Dhaka City ${ }^{(13)}$. It was also reported that As, $\mathrm{Cd}, \mathrm{Pb}, \mathrm{Cr}$ and $\mathrm{Ni}$ concentration for most of the fruit vegetable samples collected from Tangail industrial area of Bangladesh exceeded the standard value ${ }^{(14)}$. The concentration of $\mathrm{Cd}$ and $\mathrm{Cr}$ in cucumber and tomato collected from Isfahan of Iran was significantly higher than the standard value ${ }^{(15)}$.

Both $\mathrm{Cr}$ (III) and $\mathrm{Cr}$ (IV) can be toxic to plants and animals, $\mathrm{Cr}$ (III) toxicity occurs in higher concentrations and this form is actually an essential nutrient to human and other animals. $\mathrm{Cr}$ (VI), on the other hand tends to be more mobile and bioavailable than $\mathrm{Cr}$ (III) in surface and subsurface environments ${ }^{(16)}$. Together with $\mathrm{Hg}, \mathrm{Pb}$ and $\mathrm{Cd}$ are the big three heavy metal poisons and are not known for any essential biological function ${ }^{(17)}$. Nickel is an element that occurs in the environment only at very low level end is essential in small doses. Copper, zinc, iron and manganese are essential element for normal 
growth and development in human being, although it is toxic at high concentrations ${ }^{(18)}$. The result obtained from this analysis revealed that the concentration of heavy metals in the studied fruit vegetables to be from background levels for some metals to excess level when compared with the standard limits. The excess level of heavy metals in vegetables may be incorporated via contaminated soil, irrigated waste water or others (2). Soils may be contaminated by accumulation of heavy metals and metalloids through emissions from rapidly expanding industrial areas, mine tailings, disposal of high metal wastes, leaded gasoline and paints, land application of fertilizers, animal manures, sewage sludge, pesticides, wastewater irrigation, coal combustion residues, spillage of petrochemicals and atmospheric deposition ${ }^{(19)}$.

Intensive uncontrolled operation of various industries has resulted in the release of trace metals in the local environment ${ }^{(13)}$. Vegetables grown in the nearby sites are contaminated by relevant metals, especially $\mathrm{Zn}, \mathrm{Cd}$ and $\mathrm{Pb}$. Tannery industries around Dhaka city acts as the major source of $\mathrm{Cr}^{(20)}$. Transportation and marketing of vegetables may elevate the levels of heavy metals in vegetables through surface deposition(21).

Average Daily Intake (ADI) of heavy metals: The average daily intakes of heavy metals were calculated according to the concentration of each metal in each vegetable. The mean ADI values and the Permitted Maximum Tolerable Daily Intake (PMTDI) of the studied metals via dietary intake of the studied fruit vegetables are represented in Table 2.

Mean $\mathrm{ADI}$ values of $\mathrm{Cr}, \mathrm{Pb}, \mathrm{Ni}$ and $\mathrm{Zn}$ from the consumption of studied fruit vegetables varied significantly $(\mathrm{p}<0.05)$, but mean $\mathrm{ADI}$ values of $\mathrm{Cd}, \mathrm{Cu}, \mathrm{Fe}$ and $\mathrm{Mn}$ revealed no significant variation (Table 2). Mean ADI values of all the heavy metals were below the PMTDI endorsed by FAOMHO(11), RDA(22), JECFA(23), $\mathrm{WHO}^{(24)}$ and $\mathrm{NIN}^{(25)}$ (Table 3). Mean ADI values of $\mathrm{Cr}, \mathrm{Cd}, \mathrm{Pb}, \mathrm{Ni}, \mathrm{Cu}, \mathrm{Zn}, \mathrm{Fe}$ and $\mathrm{Mn}$ ranged from 0.012 to $0.202,0.001$ to $0.002,0.00$ to $0.042,0.003$ to $0.031,0.070$ to $0.174,0.947$ to $4.682,0.857$ to 1.215 and 0.145 to $0.381 \mathrm{mg} /$ person/day, respectively. The average daily intake of heavy metals in fruit vegetables were also reported lower than the permitted maximum tolerable daily intake(24). But average daily intakes of heavy metals were reported higher than PMTDI by Kacholi and Sahu(5); Zhuang et al. ${ }^{(26)}$ and Sridhara Chary et al. ${ }^{(27)}$.

The decreasing order of mean average daily intake of $\mathrm{Cr}$ from consumption of the studied fruit vegetables was Brinjal $>$ Tomato $>$ Lady's finger $>$ Pumpkin $>$ Snake gourd $>$ Cucumber. The maximum ADI value was $0.002 \mathrm{mg} /$ person $/ \mathrm{kg}$ for dietary intake of Lady's finger and Brinjal and the minimum value was $0.001 \mathrm{mg} /$ person $/ \mathrm{kg}$ for dietary intake of Pumpkin, tomato, Snake gourd and Cucumber. The order of contribution for $\mathrm{Pb}$ intake via dietary consumption of studied fruit vegetables was Pumpkin $>$ Brinjal $>$ Tomato and Snake gourd>Lady's finger and Cucumber, for intake of Ni was Snake gourd> Cucumber $>$ Brinjal and Pumpkin $>$ Lady's finger $>$ Tomato, for intake of $\mathrm{Cu}$ was Lady's finger $>$ Brinjal $>$ Pumpkin $>$ Snake gourd $>$ Tomato $>$ Cucumber, for Zn intake was Lady's finger $>$ Pumpkin $>$ Cucumber $>$ Brinjal $>$ Tomato $>$ Snake gourd, for intake of Fe was 
Brinjal $>$ Pumpkin $>$ Snake gourd $>$ Lady's finger $>$ Cucumber $>$ Tomato and for Mn intake was Snake gourd $>$ Lady's finger $>$ Brinjal $>$ Tomato $>$ Cucumber $>$ Pumpkin.

Hazard Quotient (HQ) and Hazard Index (HI): The Hazard Quotient (HQ) values of heavy metals for intake of fruit vegetables are represented in Table 3. The findings showed that HQ values of all heavy metals were less than 1 in all the fruit vegetables. When HQ exceeds 1, these means there are potential health effects from exposure(8). So, consumers are said to be free of risks for consumption of the studied fruit vegetables. The $\mathrm{HQ}$ values for $\mathrm{Cr}, \mathrm{Cd}, \mathrm{Pb}, \mathrm{Ni}, \mathrm{Cu}, \mathrm{Zn}, \mathrm{Fe}$ and $\mathrm{Mn}$ were ranged from 0.03-0.33, 0.03-0.07, $0.00-0.17,0.003-0.03,0.03-0.07,0.05-0.26,0.02-0.03$ and $0.02-0.05$, respectively (Table 3 ).

Table 2. Average daily intake of heavy metals (mg/person/day).

\begin{tabular}{lcccccccc}
\hline \multirow{2}{*}{$\begin{array}{c}\text { Name of } \\
\text { vegetables }\end{array}$} & \multicolumn{7}{c}{ Average Daily Intake (mg/person/day) } \\
\cline { 2 - 9 } Lady's finger & $0.014 \mathrm{ab}$ & $0.002 \mathrm{a}$ & $0.000 \mathrm{a}$ & $0.006 \mathrm{a}$ & $0.174 \mathrm{a}$ & $4.682 \mathrm{~b}$ & $0.916 \mathrm{a}$ & $0.323 \mathrm{a}$ \\
Pumpkin & $0.013 \mathrm{ab}$ & $0.001 \mathrm{a}$ & $0.042 \mathrm{~b}$ & $0.012 \mathrm{ab}$ & $0.124 \mathrm{a}$ & $2.694 \mathrm{ab}$ & $1.132 \mathrm{a}$ & $0.145 \mathrm{a}$ \\
Tomato & $0.017 \mathrm{ab}$ & $0.001 \mathrm{a}$ & $0.002 \mathrm{a}$ & $0.003 \mathrm{a}$ & $0.081 \mathrm{a}$ & $1.517 \mathrm{a}$ & $0.857 \mathrm{a}$ & $0.235 \mathrm{a}$ \\
Brinjal & $0.059 \mathrm{~b}$ & $0.002 \mathrm{a}$ & $0.006 \mathrm{a}$ & $0.012 \mathrm{ab}$ & $0.132 \mathrm{a}$ & $1.615 \mathrm{a}$ & $1.215 \mathrm{a}$ & $0.237 \mathrm{a}$ \\
Snake gourd & $0.008 \mathrm{ab}$ & $0.001 \mathrm{a}$ & $0.002 \mathrm{a}$ & $0.031 \mathrm{~b}$ & $0.087 \mathrm{a}$ & $0.947 \mathrm{a}$ & $0.928 \mathrm{a}$ & $0.381 \mathrm{a}$ \\
Cucumber & $0.006 \mathrm{a}$ & $0.001 \mathrm{a}$ & $0.000 \mathrm{a}$ & $0.013 \mathrm{ab}$ & $0.070 \mathrm{a}$ & $2.141 \mathrm{a}$ & $0.874 \mathrm{a}$ & $0.215 \mathrm{a}$ \\
\hline \multicolumn{1}{c}{ PMTDI } & $\mathbf{0 . 2 0 ^ { \mathrm { a } }}$ & $\mathbf{0 . 0 4 6 ^ { \mathbf { b } }}$ & $\mathbf{0 . 2 1} \mathbf{b}$ & $\mathbf{0 . 3 0}$ & $\mathbf{2 . 0 0 ^ { \mathrm { d } }}$ & $\mathbf{2 0 . 0 0 ^ { \mathrm { d } }}$ & $\mathbf{1 7 . 0 0 ^ { \mathrm { d } }}$ & $\mathbf{2 . 0 - 5 . 0}$ \\
\hline
\end{tabular}

Mean values with same letter (s) in a column do not differ significantly from each other at $5 \%$ level by DMRT. aRDA, 1989; bJECFA, 2003; cWHO, 1996; dFAO MHO, 2011; eNIN, 2009.

The comparison among fruit vegetables revealed that $\mathrm{HQ}$ values for the metals decreased in the following order:

Cr: Brinjal $>$ Tomato $>$ Lady's finger $>$ Pumpkin $>$ Snake gourd $>$ Cucumber,

Cd: Brinjal $>$ Lady's finger $>$ Tomato $>$ Cucumber $>$ Pumpkin $>$ Snake gourd,

Pb: Pumpkin $>$ Brinjal $>$ Tomato $>$ Snake gourd $>$ Lady's finger and Cucumber,

Ni: Snake gourd $>$ Cucumber $>$ Pumpkin \& Brinjal $>$ Lady's finger $>$ Tomato,

Cu: Lady's finger $>$ Brinjal $>$ Pumpkin $>$ Snake gourd $>$ Tomato $>$ Cucumber,

Zn: Lady's finger $>$ Pumpkin $>$ Cucumber $>$ Brinjal $>$ Tomato $>$ Snake gourd,

Fe: Brinjal $>$ Pumpkin $>$ Lady's finger \& Snake gourd $>$ Cucumber $>$ Tomato and

Mn: Snake gourd $>$ Lady's finger $>$ Tomato \& Brinjal $>$ Cucumber $>$ Pumpkin. 
The results in Fig. 1 show that the highest and the lowest values of Hazard Index (HI) were 0.636 and 0.265 for consumption of Brinjal and Snake gourd, respectively. The HI values were found in the decreasing order of Brinjal $>$ Lady's finger $>$ Pumpkin $>$ Tomato $>$ Cucumber $>$ Snake gourd. When the HI surpasses unity, this implies that consumption of vegetables can cause health effects. For this study, the consumption of the fruit vegetables poses no health risks as the $\mathrm{HI}$ values for all the fruit vegetables were below 1 .

Table 3. Hazard Quotient for individual heavy metals and Hazard Index for consumption of individual fruit vegetables.

\begin{tabular}{|c|c|c|c|c|c|c|c|c|c|}
\hline \multirow{2}{*}{$\begin{array}{l}\text { Name of } \\
\text { vegetables }\end{array}$} & \multicolumn{8}{|c|}{ Hazard quotient (HQ) } & \multirow{2}{*}{$\begin{array}{c}\text { Hazaro } \\
\text { index } \\
(\mathrm{HI})\end{array}$} \\
\hline & $\mathrm{Cr}$ & $\mathrm{Cd}$ & $\mathrm{Pb}$ & $\mathrm{Ni}$ & $\mathrm{Cu}$ & $\mathrm{Zn}$ & $\mathrm{Fe}$ & $\mathrm{Mn}$ & \\
\hline Lady's finger & 0.079 & 0.058 & 0.000 & 0.005 & 0.073 & 0.260 & 0.022 & 0.038 & 0.535 \\
\hline Pumpkin & 0.070 & 0.035 & 0.174 & 0.010 & 0.052 & 0.150 & 0.027 & 0.017 & 0.534 \\
\hline Tomato & 0.093 & 0.042 & 0.010 & 0.003 & 0.034 & 0.084 & 0.020 & 0.028 & 0.314 \\
\hline Brinjal & 0.328 & 0.071 & 0.025 & 0.010 & 0.055 & 0.090 & 0.029 & 0.028 & 0.636 \\
\hline Snake gourd & 0.046 & 0.028 & 0.009 & 0.026 & 0.036 & 0.053 & 0.022 & 0.045 & 0.265 \\
\hline Cucumber & 0.034 & 0.039 & 0.000 & 0.011 & 0.029 & 0.119 & 0.021 & 0.026 & 0.278 \\
\hline
\end{tabular}

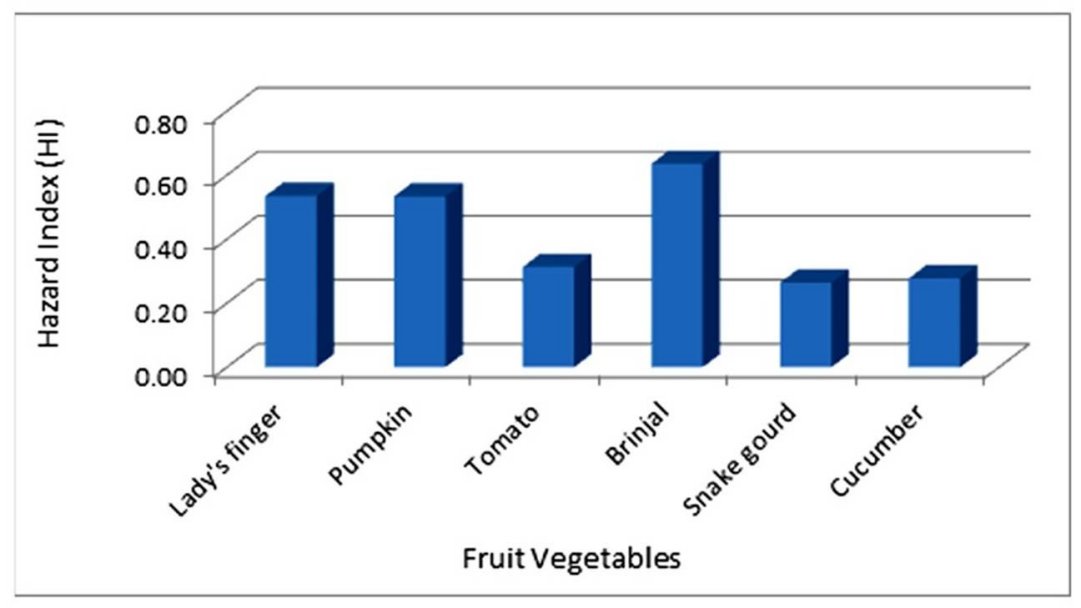

Fig. 1. Hazard Index for consumption of fruit vegetables.

The Hazard Quotient (HQ) has been recognized as a useful parameter for evaluation of risk associated with consumption of metal contaminated food $\operatorname{crops}^{(34)}$ and Hazard index (HI) is estimated as the sum of hazard quotients when more than one heavy metal 
is involved. In the present study, though all the HQ and the HI values were below 1 for consumption of studied fruit vegetables, the concentration of heavy metals in different fruit vegetables were higher than the MPL which indicated that there might be a potential health risk via dietary intake of these vegetables.

Higher HQ and HI value in vegetables collected from different regions of Bangladesh was reported earlier. Islam and Hoque reported that HQ was 1.33, 1.18 and 1.11 via intake of Pumpkin, Brinjal and Bottle gourd, respectively, which were collected around the industrial area of Dhaka, Bangladesh ${ }^{(13)}$. But, Shaheen et al. ${ }^{(28)}$ reported that HI for consumption of Brinjal and Tomato were below unity, but HI for consumption of Bean was above 1 (1.194) collected from 30 different agro-ecological zones in Bangladesh(28). Kacholi and Sahu also reported that HI values for intake of Lady's finger and Brinjal were below 1, which were collected from Temeke municipality area of Dar es Salaam, Tanzania(5).

In Bangladesh, vegetable make up approximately $16 \%$ of the total $\operatorname{diet}^{(29)}$. This study exhibited that the concentration of heavy metals in some vegetables were higher than the recommended limit. The reason for higher intake of heavy metals such as $\mathrm{Cr}, \mathrm{Cd}, \mathrm{Pb}, \mathrm{Ni}$ and $\mathrm{Cu}$ etc. may be due to irrigation of agricultural fields around Dhaka city with water contaminated with wastes from different industries. Atmospheric deposition of the metals around industrial areas and roadside agricultural fields may be another reason for the higher concentration of $\mathrm{Pb}$ and $\mathrm{Ni}$ in vegetables. The application of numerous biosolids (e.g., livestock manures, composts and municipal sewage sludge) to land inadvertently and indiscriminate use of agrochemicals leads to accumulation of heavy metals such as $\mathrm{Cd}, \mathrm{Cr}, \mathrm{Cu}, \mathrm{Pb}, \mathrm{Ni}$ and so forth in soil(30).

It is suggested that monitoring and assessment of heavy metal concentrations in different vegetables from the market as well as production sites require more extensive studies for assessing the risk of health hazards to the human beings and to prevent excessive buildup of these heavy metals in the human food chain.

\section{References}

1. Turkdogan MK, F Kilicel, K Kara, I Tuncer and I Uygan 2003. Heavy metals in soil, vegetables and fruits in the endemic upper gastrointestinal cancer region of Turkey. Environ. Toxicol. Pharmacol. 13: 175-179.

2. Linkon MR, MS Satter, SA Jabin, N Abedin, MF Islam, LA Lisa and DK Paul 2015. Mineral and heavy metal contents of some vegetable available in local market of Dhaka city in Bangladesh. J. Environ. Sci. Toxicol. Food Technol. 9: 1-6.

3. Voutsa D, A Grimanis and C Samara 1996. Trace elements in vegetables grown in an industrial area in relation to soil and air particulate matter. Environ. Pollut. 94: 325-335.

4. Sharma RK, M Agrawal and FM Marshall 2008. Heavy metal (Cu, Zn, Cd and Pb) contamination of vegetables in urban India: A case study in Varanasi. Environ. Pollut. 154: 254-263. 
5. Kacholi DS and M Sahu 2018. Levels and health risk assessment of heavy metals in soil, water and vegetables of Dar es Salam, Tanzania. J. Chem. pp. 1-9.

6. HIES (Household Income and Expenditure Survey) 2011. Bangladesh Bureau of Statistics, Statistics Division, Ministry of Planning, Dhaka, Bangladesh. pp. 1-50.

7. JECFA (Joint FAO MHO Expert Committee on Food Additives) 1993. Evaluation of certain food additives and contaminants: 41 ${ }^{\text {st }}$ report of JECFA. Technical Reports Series no. 837.World Health Organization, Geneva, Switzerland. pp. 10-15.

8. Bermudez GMA, R Jasan, R Pl'a and ML Pignata 2011. Heavy metal and trace element concentrations in wheat grains: Assessment of potential non-carcinogenic health hazard through their consumption. J. Hazard. Mater. 193: 264-271.

9. WHO/FAO 2013. Guidelines for the safe use of wastewater and food stuff. Wastewater use in agriculture. World Health Organization and Food and Agriculture Organization (FAO), Geneva, Switzerland. pp. 988.

10. Gomez KA and AA Gomez 1984. Statistical Procedures for Agricultural Research (2 ed.). John Wiley and Sons, New York. pp. 680.

11. FAOMHO 2011. Codex Alimentarius Commission. Joint FAOMHO food standards programme codex committee on contaminants in foods. Food CF 5 INF/1. Fifth Session. The Hague, The Netherlands, 21 - 25 March 2011. pp. 3-38.

12. FAO WHO 2001. Food additives and contaminants, Joint Codex Alimentarius Commision. FAO $M$ NHO Food Standards Programme, ALINORM 01/12A: 1-289.

13. Islam MS and MF Hoque 2014. Concentration of heavy metals in vegetables around the industrial area of Dhaka city, Bangladesh and health risk assessment. Int. Food. Res. J. 21(6): 2121-2126.

14. Proshad R, T Kormokerb, MS Islam and K Chandrad 2019. Potential health risk of heavy metals via consumption of rice and vegetables grown in the industrial areas of Bangladesh. Hum. Ecol. Risk Assess. 12: 27-35.

15. Jafarian A and M Alehashem 2012. Heavy metal contamination of vegetables in Isfahan, Iran. Res. Pharm. Sci. 8(1): 51-58.

16. Campbell PGC 2006. Cadmium-A priority pollutant. Environ. Chem. 3(6): 387-388.

17. Akinyele IO and O Osibanjo 1982. Levels of trace element in hospital diet. Food Chem. 8: 247252.

18. Nriagu J 2007. Zinc Toxicity in Humans. Elsevier Publication. Michigan. pp. 71-87.

19. Chamon AS, MH Gerzabek, MN Mondol, SM Ullah, M Rahman and WEH Blum 2005. Influence of soil amendments on heavy metal accumulation in crops on polluted soils of Bangladesh. Commun. Soil Sci. Plant Anal. 36(7-8): 907-924.

20. Sharma RK, M Agrawal and FM Marshall 2009. Heavy metals in vegetables collected from production and market sites of tropical urban area of India. Food Chem. Toxicol. 47: 583-591.

21. FAO MHO 2007. Joint FAOMHO Food Standards Program Code Alimentarius Commission $13^{\text {th }}$ Session, Report of the Thirty Eight Session of the Codex Committee on Food Hygiene, Houston, Texus, USA. ALINORM 07/30/13. pp. 1-189. 
22. RDA (Recommended Dietary Allowances) 1989. National Research Council (US) Subcommittee on the Tenth Edition of the Recommended Dietary Allowances. Washington (DC): National Academies Press (US). pp. 1-190.

23. JECFA (Joint FAO MHO Expert Committee on Food Additives) 2003. Food additives and food contaminants. FAO procedural guidelines for the Joint FAOMHO Expert Committee on Food Additives Rome, February 2003.

24. WHO (World Health Organization) 1996. Permissible limits of heavy metals in soil and plants. Geneva, Switzerland. pp. 15-18.

25. NIN (National Institute of Nutrition) 2009. Nutreint requirements and recommended dietary allowances for Indians. A Report of the expert group of the Indian Council of Medical Research, Jamai-Osmania PO, Hyderabad - 005 604, India. pp. 15-31.

26. Zhuang P, MB McBride, H Xia, N Li and Z Li 2009. Health risk from heavy metals via consumption of food crops in the vicinity of Dabaoshan mine, South China. Sci. Total Environ. 407: 1551-1561.

27. Sridhara Chary N, CT Kamala and D Samual suman Raj 2008. Assessing risk of heavy metals from consuming food grown on irrigated soils and food chain transfer. Ecooxicol. Environ. Safety. 69(3): 513-524.

28. Shaheen N, NM Irfan, IN Khan, S Islam, MS Islam and MK Ahmed 2016. Presence of heavy metals in fruits and vegetables: Health risk implications in Bangladesh. Chemosphere. 152: 431-438.

29. Alam MGM, ET Snow and A Tanaka 2003. Arsenic and heavy metal contamination of vegetables grown in Samta Village, Bangladesh. Sci. Total Environ. 308: 83-96.

30. Basta NT, JA Ryan and RL Chaney 2005. Trace element chemistry in residual-treated soil: key concepts and metal bioavailability. J. Environ. Qual. 34(1): 49-63.

(Manuscript received on 16 January, 2020; revised on 27 December, 2020) 